Jurnal Informa : Jurnal Penelitian dan Pengabdian Masyarakat. p-ISSN : 2442-7942, e-ISSN 2716-5051

Volume 7 Nomor 1 Juni 2021

\title{
Sistem Pendukung Keputusan Penentuan Status Gizi Balita Dengan Metode Fuzzy Tahani (Menggunakan Standar Antropometri Anak)
}

\author{
Sumedi Joko Susilo ${ }^{1)}$, Supatman ${ }^{2)}$ \\ Program Studi Informatika, Fakultas Teknologi Informasi, Universitas Mercu Buana Yogyakarta, \\ Jl. Jembatan Merah, No. 84.C. Gejayan, Yogyakarta 55281, Indonesia \\ Email: ${ }^{1}$ sumedijs@gmail.com, ${ }^{2}$ keliksupatman@gmail.com
}

\begin{abstract}
Abstrak
Pertumbuhan manusia pada usia balita adalah laju pertumbuhan yang paling penting, pada waktu itu mengalami pertumbuhan yang krusial karena sangat menentukan kehidupan balita tersebut di usia selanjutnya. Karena pada usia ini tumbuh kembang balita sangatlah pesat. Salah satu permasalahan yang ditemui dalam bidang kesehatan adalah gizi balita. Dalam menentukan gizi balita menggunakan beberapa kreteria - kriteria antara lain jenis kelamin, usia balita, berat badan dan panjang badan/tinggi badan. Untuk membantu dalam pemantuan gizi balita dalam penelitian ini menggunakan metode fuzzy tahani dengan menggunakan standar antropometri anak. Berdasarkan hasil pengujian terhadap sistem pendukung keputusan (SPK) status gizi balita yang telah dibangun dengan menggunakan metode fuzzy Tahani dan pengujian menggunakanstandar baku antropometri memiliki hasil $85,71 \%$ dari 35 data yang diujikan terdapat 5 yang tidak sesuai, sehingga dapat disimpulkan bahwa unjuk kerja sistem berhasil.
\end{abstract}

Kata kunci: Antropometri, Sistem Pendukung Keputusan, Fuzzy Tahani, Status Gizi, Balita.

\begin{abstract}
People growth at toddler period becomes the most essential growth rate. At that time they experience a crucial growth because it highly determines the toddler life in the future since at this age their growth and development occur rapidly. One of the problems found in the health sector is nutrition for toddlers. In determining the toddlers' nutrition, several criteria are used - the criteria include sex, toddler age, weight and height. This study used Fuzzy Tahani method with child anthropometric standard to assist monitoring the toddlers' nutrition. Based on the test results of the decision support system (SPK), it showed that there were 2 invalid data from $90 \%$ of the 20 data tested on the nutritional status of toddlers established using Fuzzy Tahani method and anthropometric standard. Therefore, it can be implied that the system performance is successful.
\end{abstract}

Key words: Anthropometry, Decision Support System, Fuzzy Tahani, Nutritional Status, Toddler

\section{PENDAhULUAN}

Pertumbuhan manusia pada usia balita adalah laju pertumbuhan yang paling penting. Balita mengalami pertumbuhan yang krusial karena sangat menentukan kehidupan balita tersebut di usia selanjutnya. Salah satu penompang tumbuh kembang balita adalah asupan nutrisi yang mencukupi kebutuhannya. Makanan bergizi sangatlah penting karena menjadi bahan baku utama tubuh balita berkembang. Kekurangan gizi pada balita dapat menyebabkan berbagai masalah mulai dari yang paling ringan adalah daya tahan dan kesehatan balita terganggu hingga yang paling parah adalah akan menyebabkan gangguan kesehatan mental, menyebabkan postur tubuh tidak berkembang baik, atau bahkan hingga menyebabkan kematian (Febrealti, 2011).

Untuk melihat tingkat Kesehatan pada balita dapat diketahui melalu status gizi anak tersebut, status gizi dapat diketahui dengan cara manual yaitu dengan mengukur berat badan, tinggi badan, dan kondisi fisik lainnya yang umumnya orang tua balita akan mendatangi posyandu atau puskesmas untuk menghitungnya.

Penilaian status gizi balita dapat ditentukan melalui pengukuran tubuh manusia yang dikenal dengan istilah " Anthropometri “. Jenis nya yaitu : umur (U), berat badan 
(BB), tinggi badan (TB), lingkar kepala (LK), lingkar lengan atas (LLA), lingkar dada (LD), lingkar perut (LP), lapisan lemak bawah kulit (LLBK), tinggi lutut) (Proverawati \& Asfuah, 2009).

Untuk menentukan klasifikasi data-data antropologi anak ke dalam status perkembangan gizi menggunakan metode Logika Fuzzy. Logika fuzzy merupakan suatu cara untuk memetakan suatu ruang input ke dalam suatu ruang output. Untuk menentukan klasifikasi status gizi balita yaitu dengan perhitungan z score. Indikator yang digunakan dalam penelitian ini diantaranya berat badan menurut umur $(\mathrm{BB} / \mathrm{U})$, tinggi badan menurut umur $(\mathrm{TB} / \mathrm{U})$, dan berat badan menurut tinggi (BB/TB). Metode untuk menilai kepastian status gizi menggunakan fuzzy logic sehingga dapat menentukan status gizi balita dengan lebih baik yang disertai dengan nilai derajat keanggotaan. Dengan menerapkan metode fuzzy logic yang membantu memberikan ketetapan kriteria yang dibutuhkan dengan identifikasi umur, tinggi badan, dan berat badan (Fidiantoro \& Setiadi, 2013).

Berdasarkan latar belakang diatas, untuk membantu dalam pemantuan gizi dan tumbuh kembang balita, maka penulis mengambil judul : "Sistem Pendukung Keputusan Penentuan Status Gizi Balita Dengan Metode Fuzzy Tahani (Menggunakan Standar Antropometri Anak)".

\section{TINJAUAN PUSTAKA}

Penelitian tentang Penerapan Fuzzy Logic dalam Sistem Kenaikan Jabatan. Sebelumnya penilaian berdasarkan intelektual, sikap kerja, dan perilaku. Nilai tersebut menunjukan kelayakan karyawan untuk naik level jabatannya perhitungan ini masih menggunakan microsoft exel, sehingga hasilnya kurang obyektif. Oleh karena itu menggunkan metode fuzzy logic dapat mengatasi permasalahan dalam perhitungan dan pengambilan keputusan yang ada dengan hasil yang sama dalam kategori yang berbeda (Gufron, 2010).

Pemenuhan gizi seimbang yang sesuai dengan kondisi tubuh guna memenuhi standar kesehatan terkadang menjadi kendala dalam mengatur pemenuhan gizi yang berimbang. Oleh sebab itu sistem ini dibuat agar dapat membantu beberapa pihak seperti ahli gizi rumah sakit, pihak yang mengatur gizi pasien, dan lain sebagainya dengan menerapkan metode fuzzy logic (FL) yang membantu memberikan ketetapan kriteria yang dibutuhkan dengan identifikasi umur, tinggi badan, dan berat badan (Anita, 2016).

Pemantauan tumbuh kembang balita sangat penting dilakukan untuk mengetahui adanya gangguan pertumbuhan balita sejak dini, dengan cara melakukan pengukuran berat badan sebagai cara terbaik untuk menilai status gizi balita tiap bulannya sehingga tumbuh kembang anak akan terpantau (Rahmawati, Hasanah, \& Maulindar, 2017).

Dalam penelitianya penentuan status gizi dengan parameter Indeks Massa Tubuh (IMT) menggunakan logika fuzzy, variabel input dibagi menjadi dua yaitu variabel berat dan tinggi badan. Serta satu variabel output, yaitu variabel nilai gizi (Wulandari, 2011).

Penelitian status gizi berdasarkan pengukuran antropometri dengan metode fuzzy logic untuk membantu mengatasi masalah gizi. Pada kegiatan ini data yang digunakan adalah data-data antropometri yaitu berat badan (BB) dan tinggi badan (TB). Sedangkan pengelompokan berdasarkan indeks massa tubuh yakni gizi sangat kurang, gizi kurang, gizi normal, gizi lebih, dan gizi sangat lebih (Sari, Dewanto, \& Surateno, 2017).

Penelitianya berjudul "Sistem
Pendukung Keputusan Gizi Menggunakan Metode Simple Additive Weighting Berbasis WEB." penelitian ini mengatasi masalah kurang akuratnya data hasil perhitungan status gizi balita jika dihitung dengan cara yang manual (Ulansari, Amini, \& Mulyati, 2019).

Penelitian pemilihan karyawan terbaik pada PT. Culture Royale masih kurang objektif, dengan menggunakan Fuzzy Tahani data-data dari kriteria tersebut diolah untuk mendapatkan hasil yang terbaik (Astari \& Komarudin, 2018).

\section{METODE PENELITIAN}

Setiap tahapan penelitian memiliki proses yang dapat dilihat pada Gambar 1 dibawah ini. 


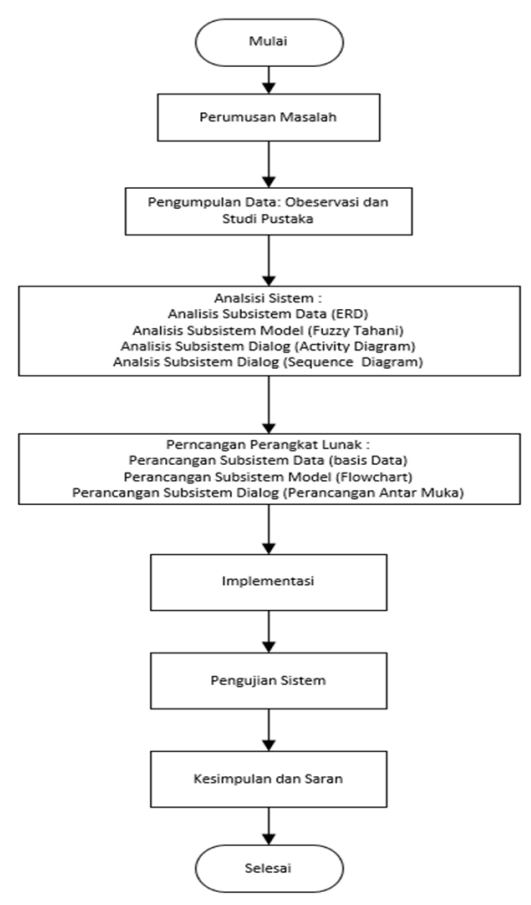

Gambar 1. Jalan Penelitian

Dalam penelitian ini akan membangun sebuah aplikasi web yang dapat menghitung status gizi pada balita berdasarkan berat badan (BB) dan tinggi badab (TB) sehingga mempermudahkan orang tua dalam memonitor perkembangan balitanya.

Pengumpulan data merupakan salah satu hal yang terpenting dalam memecahkan suatu masalah. Metode ini bertujuan agar mendapat hasil yang dapat dipertanggung jawabkan. Adapun metode tersebut adalah :

1) Metode Observasi

2) Metode Wawancara

3) Metode Studi Pustaka

Tahap Analisis Sistem, dalam tahap ini merupakan tahap dimana peneliti mendesain sistem. Dalam desain ini terdapat beberapa perancangan yaitu perancangan interface, perancangan prosedur, perancangan fitur, perancangan arsitektur, perancangan aplikasi, perancangan data dan perancangan fitur.

Tahap Perancangan Peangkat Lunak, dalam tahap ini peneliti mulai membuat sistem. Dalam pembuatan ini dibuat sesuai desain yang telah dirancang dan menggunaka data yang telah dikumpulkan

Tahap pengujian sistem yaitu tahap dimana peneliti menguji hasil pembuatan sistem. Tahap selanjutnya kemudian peneliti akan menentukan kesimpulan dan saran.

\section{HASIL DAN PEMBAHASAN}

Kategori dan ambang batas status gizi anak menurut standar antropometri dapat dilihat pada tabel.

Tabel 1. Kategori dan Ambang Batas Status Gizi Anak (Kemenkes, 2020)

\begin{tabular}{|c|c|c|}
\hline Indeks & Kategori Status Gizi & Ambang Batas \\
\hline \multirow{4}{*}{$\begin{array}{l}\text { Berat Badan menurut Umur } \\
(\mathrm{BB} / \mathrm{U}) \text { anak usia } 0-60 \text { bulan }\end{array}$} & Berat badan sangat kurang (severely underweight) & $<-3 \mathrm{SD}$ \\
\hline & Berat badan kurang (underweight) & $-3 \mathrm{SD} s d<-2 \mathrm{SD}$ \\
\hline & Berat badan normal & $-2 \mathrm{SD}$ sd $+1 \mathrm{SD}$ \\
\hline & Risiko Berat badan lebih & $>+1 \mathrm{SD}$ \\
\hline \multirow{4}{*}{ 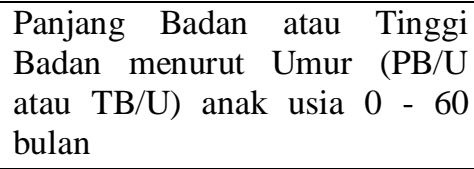 } & Sangat pendek (severely stunted) & $<-3 \mathrm{SD}$ \\
\hline & Pendek (stunted) & $-3 \mathrm{SD}$ sd $<-2 \mathrm{SD}$ \\
\hline & Normal & -2 SD sd +3 SD \\
\hline & Tinggi & $>+3 \mathrm{SD}$ \\
\hline \multirow{6}{*}{$\begin{array}{l}\text { Berat Badan menurut Panjang } \\
\text { Badan atau Tinggi Badan } \\
(\mathrm{BB} / \mathrm{PB} \text { atau } \mathrm{BB} / \mathrm{TB}) \text { anak usia } \\
0-60 \text { bulan }\end{array}$} & Gizi buruk (severely wasted) & $<-3 \mathrm{SD}$ \\
\hline & Gizi kurang (wasted) & $-3 \mathrm{SD} s d<-2 \mathrm{SD}$ \\
\hline & Gizi baik (normal) & $-2 \mathrm{SD}$ sd $+1 \mathrm{SD}$ \\
\hline & Berisiko gizi lebih (possible risk of overweight) & $>+1 \mathrm{SD} s d+2 \mathrm{SD}$ \\
\hline & Gizi lebih (overweight) & $>+2 \mathrm{SD}$ sd $3 \mathrm{SD}$ \\
\hline & Obesitas (obese) & $>+3 \mathrm{SD}$ \\
\hline
\end{tabular}

Berikut ini contoh pengujian penentuan status gizi balita menggunakan menggunakan standar pengukuruan antropometri. Balita bernama Nizama Afkar Rasyid pada tanggal 20 Mei 2017, sehingga saat ini berumur 42 bulan 13 bari, mempunyai berat badan $13,7 \mathrm{~kg}$, dan tinggi badan $98 \mathrm{~cm}$. 


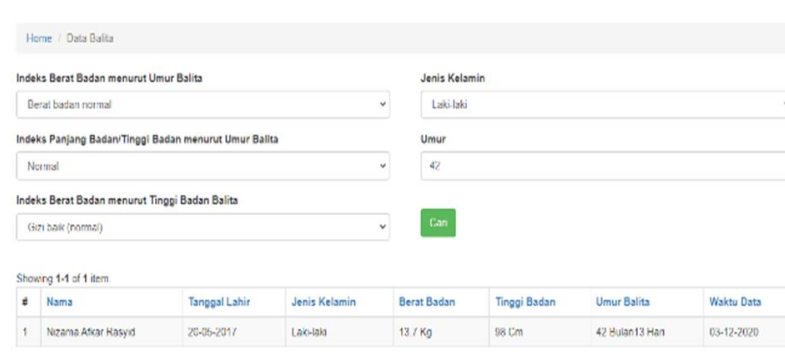

Gambar 2. Query Database Fuzzy

Selanjutnya dibuktikan dengan perhitungan dari data standar berat badan menurut umur $(\mathrm{BB} / \mathrm{U})$ dihitung simpangan baku (SD) dengan menggunakan fungsi keanggotaan fuzzy. Presentasi derajat keanggotaan berat badan dapat dilihat pada Gambar 3 di bawah ini.

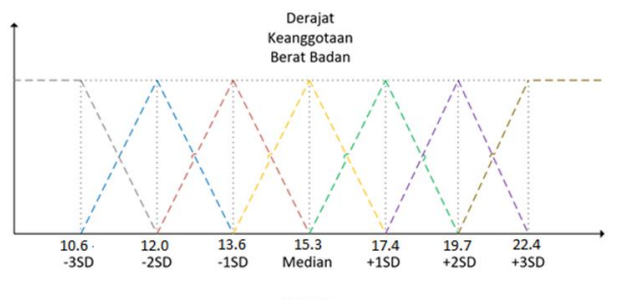

Gambar 3. Representasi Kurva Derajat Keanggotaan Berat Badan

Dengan parameter data balita berat badannya adalah $13.7 \mathrm{~kg}$ maka dihitung derajat keanggotaan pada dua kurva yaitu kurva Median dan -1SD yang saling beririsan. Perhitungan derajat keanggotaan fuzzy dapat dilihat dibawah ini.

Perhitungan Fungsi Keanggotaan -1SD :

$$
\begin{aligned}
-1 \mathrm{SD} & =\left\{\begin{array}{l}
1 \quad ; \mathrm{BB} \leq 12.0 \text { atau } \mathrm{BB} \geq 15.3 \\
\frac{(\mathrm{BB}-12.0)}{(13.6-12.0)} ; 12.0<\mathrm{BB} \leq 13.6 \\
\frac{(15.3-\mathrm{BB})}{15.3-13.6)} \quad ; 13.6<\mathrm{BB}<15.3
\end{array}\right. \\
-1 \mathrm{SD} & =\frac{(15.3-\mathrm{BB})}{(15.3-13.6)} \\
& =\frac{(15.3-13.7)}{(15.3-13.6)} \\
& =\frac{1.6}{1.7} \\
& =0.94
\end{aligned}
$$

Perhitungan Fungsi Keanggotaan Median :

$$
\begin{aligned}
& \text { Median }=0 \quad ; \mathrm{BB} \leq 13.6 \text { atau } \mathrm{BB} \geq 17.4 \\
& \begin{cases}\frac{(\mathrm{BB}-13.6)}{(15.3-13.6)} & ; 13.6<\mathrm{BB} \leq 15.3 \\
\frac{17.4-\mathrm{BB})}{(17.4-15.3)} & ; 15.3<\mathrm{BB}<17.4\end{cases} \\
& \text { Median }=\frac{(\mathrm{BB}-13.6)}{(15.3-13.6)} \\
& =\frac{13.7-13.6}{(15.3-13.6)} \\
& =\frac{0.1}{1.7}
\end{aligned}
$$

$$
=0.05
$$

Nilai keanggotaan untuk simpangan baku -1SD adalah 0.94 sedangkan nilai keanggotaan untuk simpangan baku Median adalah 0.05 maka kesimpulan nilai keanggotaan untuk berat badan balita adalah simpangan baku -1SD.

Selanjutnya dapat dilihat di Tabel 1 kategori ambang batas status gizi anak bahwa nilai ambang batas untuk simpangan baku -1SD pada indeks berat badan menurut umur $(\mathrm{BB} / \mathrm{U})$ adalah berat badan normal.

Selanjutnya dari data standar panjang badan menurut umur $(\mathrm{PB} / \mathrm{U})$ dihitung simpangan baku (SD) dengan menggunakan fungsi keanggotaan fuzzy. Presentasi derajat keanggotaan panjang badan dapat dilihat pada Gambar 4 di bawah ini.

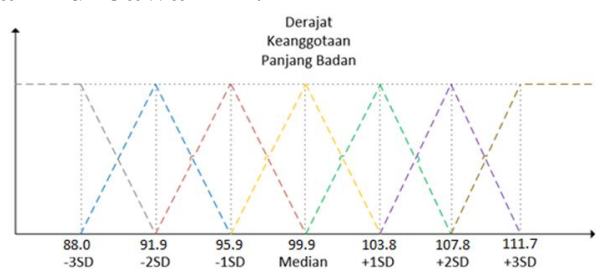

Gambar 4. Representasi Kurva Derajat Keanggotaan Panjang Badan

Dengan parameter data balita panjang badannya adalah $98 \mathrm{Cm}$ maka dihitung derajat keanggotaan pada dua kurva yaitu kurva Media dan -1SD yang saling beririsan. Perhitungan derajat keanggotaan fuzzy dapat dilihat di bawah ini.

Perhitungan Fungsi Keanggotaan -1SD

$$
\begin{aligned}
& -1 \mathrm{SD}=0 \quad ; \mathrm{PB} \leq 91.9 \text { atau } \mathrm{PB} \geq 99.9 \\
& \begin{cases}\frac{(\mathrm{PB}-91.9)}{(95.9-91.9)} & ; 91.9<\mathrm{PB} \leq 95.9 \\
\frac{(99.9-\mathrm{PB})}{(99.9-95.8)} & ; 95.9<\mathrm{PB}<99.9\end{cases} \\
& -1 \mathrm{SD}=\frac{(99.9-\mathrm{PB})}{(99.9-95.9)} \\
& =\frac{(99.9-98)}{(99.9-95.9)} \\
& =\frac{1.9}{4} \\
& =0.47
\end{aligned}
$$

Perhitungan Fungsi Keanggotaan Median

$$
\begin{aligned}
\text { Median } & = \begin{cases}0 \quad ; \mathrm{PB} \leq 95.9 \text { atau } \mathrm{PB} \geq 103.8 \\
\frac{(\mathrm{PB}-95.9)}{(99.9-95.9)} & ; 95.9<\mathrm{PB} \leq 99.9 \\
\frac{(103.8-\mathrm{PB})}{(103.8-99.9)} & ; 99.9<\mathrm{PB}<103.8\end{cases} \\
\text {-Median } & =\frac{(\mathrm{PB}-95.9)}{(99.9-95.9)} \\
& =\frac{(98-95.9)}{(99.9-95.9)} \\
& =\frac{2.1}{4}
\end{aligned}
$$




$$
=0.53
$$

Dapat dilihat pada perhitungan nilai keanggotaan untuk simpangan baku -1SD adalah 0.47 sedangkan nilai keanggotaan untuk simpangan baku Median adalah 0.53 maka kesimpulan nilai keanggotaan untuk panjang badan balita adalah simpangan baku Median.

Selanjutnya dapat dilihat di Tabel 1 kategori ambang batas status gizi anak bahwa nilai ambang batas untuk simpangan baku Median pada indeks panjang badan menurut umur $(\mathrm{PB} / \mathrm{U})$ adalah normal.

Dari data standar berat badan menurut panjang badan $(\mathrm{BB} / \mathrm{PB})$ dihitung simpangan baku (SD) dengan menggunakan fungsi keanggotaan fuzzy. Presentasi derajat keanggotaan berat badan dapat dilihat pada Gambar 5.



Gambar 5. Representasi Kurva Derajat Keanggotaan Berat Badan menurut Panjang Badan

Dengan parameter data balita berat badannya adalah $13.7 \mathrm{Kg}$ maka dihitung derajat keanggotaan pada dua kurva yaitu kurva Median dan -1SD yang saling beririsan.

Perhitungan Fungsi Keanggotaan -1SD

$$
\begin{aligned}
-1 \mathrm{SD} & =\left\{\begin{array}{l}
0 ; \mathrm{BB} \leq 12.5 \text { atau } \mathrm{BB} \geq 14.6 \\
\frac{(\mathrm{BB}-12.5)}{(14.6-12.5)} ; 12.5<\mathrm{BB} \leq 13.5 \\
\frac{(14.6-\mathrm{BB})}{14.6-13.5} ; 13.5<\mathrm{BB}<14.6
\end{array}\right. \\
-1 \mathrm{SD} & =\frac{(14.6-\mathrm{BB})}{(14.6-13.5)} \\
& =\frac{14.6-13.7)}{(14.6-13.5)} \\
& =\frac{0.9}{1.1} \\
& =0.82
\end{aligned}
$$

Perhitungan Fungsi Keanggotaan Median

$$
\text { Median }= \begin{cases}0 \quad ; \mathrm{BB} \leq 13.3 \text { atau } \mathrm{BB} \geq 15.9 \\ \frac{(\mathrm{PB}-13.5)}{(14.6-13.5)} & ; 13.5<\mathrm{BB} \leq 14.6 \\ \frac{15.9-\mathrm{BB})}{(15.9-14.6)} & ; 14.6<\mathrm{BB}<15.9\end{cases}
$$

$$
\begin{aligned}
\text { Median } & =\frac{(\mathrm{BB}-13.5)}{(14.6-13.5)} \\
& =\frac{(13.7-13.5)}{(14.6-13.5)} \\
& =\frac{0.2}{1.1} \\
& =0.18
\end{aligned}
$$

\begin{tabular}{|c|c|c|c|c|c|c|c|c|c|c|c|c|}
\hline \multirow{2}{*}{$\begin{array}{l}\mathbf{N} \\
\mathbf{o}\end{array}$} & \multirow{2}{*}{ Nama } & \multicolumn{4}{|c|}{ Data Balita } & \multicolumn{3}{|c|}{$\begin{array}{c}\text { Hasil Perhitungan Standar } \\
\text { Antropometri }\end{array}$} & \multicolumn{3}{|c|}{ Hasil Perhitungan Sistem } & \multirow{2}{*}{ Kesimpulan } \\
\hline & & Tgl Lahir & $\begin{array}{l}\text { BB } \\
(\mathrm{kg})\end{array}$ & $\begin{array}{c}\mathbf{P B} \\
(\mathrm{cm}) \\
\end{array}$ & Sex & $\mathbf{B B} / \mathbf{U}$ & $\mathrm{PB} / \mathrm{U}$ & BB/PB & $\mathrm{BB} / \mathrm{U}$ & $\mathbf{P B} / \mathrm{U}$ & BB/PB & \\
\hline 1 & $\begin{array}{l}\text { Nizama Afkar } \\
\text { Rasyid }\end{array}$ & $20 / 05 / 2017$ & 13,7 & 98 & $\mathrm{~L}$ & $\begin{array}{l}\text { Berat } \\
\text { Normal }\end{array}$ & $\begin{array}{l}\text { Tinggi } \\
\text { Normal }\end{array}$ & $\begin{array}{l}\text { Gizi Baik } \\
\text { (Normal) }\end{array}$ & $\begin{array}{l}\text { Berat } \\
\text { Normal }\end{array}$ & $\begin{array}{l}\text { Tinggi } \\
\text { Normal }\end{array}$ & $\begin{array}{l}\begin{array}{l}\text { Gizi Baik } \\
\text { (Normal) }\end{array} \\
\end{array}$ & Sesuai \\
\hline 2 & $\begin{array}{ll}\begin{array}{l}\text { Faatin } \\
\text { Hanifah }\end{array} & \text { Nur } \\
\end{array}$ & $12 / 05 / 2017$ & 12,5 & 89 & $\mathrm{P}$ & $\begin{array}{l}\text { Berat } \\
\text { Normal }\end{array}$ & Pendek & $\begin{array}{l}\text { Gizi Baik } \\
\text { (Normal) }\end{array}$ & $\begin{array}{l}\text { Berat } \\
\text { Normal }\end{array}$ & Pendek & $\begin{array}{l}\text { Gizi Baik } \\
\text { (Normal) }\end{array}$ & Sesuai \\
\hline 3 & $\begin{array}{l}\text { Ghaitsa Haura } \\
\text { Aditama }\end{array}$ & $21 / 08 / 2017$ & 11,6 & 93 & P & $\begin{array}{l}\text { Berat } \\
\text { Normal }\end{array}$ & $\begin{array}{l}\text { Tinggi } \\
\text { Normal }\end{array}$ & $\begin{array}{l}\text { Gizi Baik } \\
\text { (Normal) }\end{array}$ & $\begin{array}{l}\text { Berat Badan } \\
\text { Kurang }\end{array}$ & $\begin{array}{l}\text { Tinggi } \\
\text { Normal }\end{array}$ & $\begin{array}{l}\text { Gizi Baik } \\
\text { (Normal) }\end{array}$ & Tidak Sesuai \\
\hline 4 & $\begin{array}{l}\text { Evelina Arista } \\
\text { Dewi }\end{array}$ & 19/09/2017 & 11,9 & 88 & P & $\begin{array}{l}\text { Berat } \\
\text { Normal }\end{array}$ & Pendek & $\begin{array}{l}\text { Gizi Baik } \\
\text { (Normal) }\end{array}$ & $\begin{array}{l}\text { Berat } \\
\text { Normal }\end{array}$ & Pendek & $\begin{array}{l}\text { Gizi Baik } \\
\text { (Normal) }\end{array}$ & Sesuai \\
\hline 5 & $\begin{array}{l}\text { Adil Rizqi } \\
\text { Aditama }\end{array}$ & $04 / 08 / 2017$ & 15,5 & 94 & $\mathrm{~L}$ & $\begin{array}{l}\text { Berat } \\
\text { Normal } \\
\end{array}$ & $\begin{array}{l}\text { Tinggi } \\
\text { Normal } \\
\end{array}$ & $\begin{array}{l}\text { Gizi } \\
\text { Lebih }\end{array}$ & $\begin{array}{l}\text { Berat } \\
\text { Normal } \\
\end{array}$ & $\begin{array}{l}\text { Tinggi } \\
\text { Normal } \\
\end{array}$ & Gizi Lebih & Sesuai \\
\hline 6 & $\begin{array}{l}\text { Yusep } \\
\text { Maulana } \\
\end{array}$ & $21 / 11 / 2018$ & 12,1 & 87 & $\mathrm{~L}$ & $\begin{array}{l}\text { Berat } \\
\text { Normal }\end{array}$ & $\begin{array}{l}\text { Tinggi } \\
\text { Normal }\end{array}$ & $\begin{array}{l}\begin{array}{l}\text { Gizi Baik } \\
\text { (Normal) }\end{array} \\
\text { (Nal }\end{array}$ & $\begin{array}{l}\text { Berat } \\
\text { Normal }\end{array}$ & $\begin{array}{l}\text { Tinggi } \\
\text { Normal }\end{array}$ & $\begin{array}{l}\begin{array}{l}\text { Gizi Baik } \\
\text { (Normal) }\end{array} \\
\end{array}$ & Sesuai \\
\hline 7 & $\begin{array}{l}\text { Faiz } \\
\text { Nurohman }\end{array}$ & $29 / 06 / 2019$ & 10,6 & 72 & $\mathrm{~L}$ & $\begin{array}{l}\text { Berat } \\
\text { Normal }\end{array}$ & $\begin{array}{l}\text { Sangat } \\
\text { Pendek }\end{array}$ & Gizi lebih & $\begin{array}{l}\text { Berat } \\
\text { Normal }\end{array}$ & $\begin{array}{l}\text { Sangat } \\
\text { Pendek }\end{array}$ & Gizi lebih & Sesuai \\
\hline 8 & $\begin{array}{l}\text { Ghea Felisha } \\
\text { Geranium }\end{array}$ & $11 / 01 / 2019$ & 10 & 78 & $\mathrm{P}$ & $\begin{array}{l}\text { Berat } \\
\text { Normal }\end{array}$ & Pendek & $\begin{array}{l}\text { Gizi Baik } \\
\text { (Normal) }\end{array}$ & $\begin{array}{l}\text { Berat } \\
\text { Normal }\end{array}$ & Pendek & $\begin{array}{l}\text { Gizi Baik } \\
\text { (Normal) }\end{array}$ & Sesuai \\
\hline 9 & $\begin{array}{l}\text { Ellenia Ayra } \\
\mathrm{Z}\end{array}$ & 13/10/2019 & 7,8 & 67 & $\mathrm{P}$ & $\begin{array}{l}\text { Berat } \\
\text { Normal }\end{array}$ & $\begin{array}{l}\text { Sangat } \\
\text { Pendek }\end{array}$ & $\begin{array}{l}\text { Gizi Baik } \\
\text { (Normal) }\end{array}$ & $\begin{array}{l}\text { Berat } \\
\text { Normal }\end{array}$ & $\begin{array}{l}\text { Sangat } \\
\text { Pendek }\end{array}$ & $\begin{array}{l}\begin{array}{l}\text { Gizi Baik } \\
\text { (Normal) }\end{array} \\
\end{array}$ & Sesuai \\
\hline $\begin{array}{l}1 \\
0\end{array}$ & $\begin{array}{ll}\text { Fayza } & \text { Razka } \\
\text { P } & \end{array}$ & $15 / 12 / 2019$ & 10 & 71 & $\mathrm{~L}$ & $\begin{array}{l}\text { Berat } \\
\text { Normal }\end{array}$ & $\begin{array}{l}\text { Tinggi } \\
\text { Normal }\end{array}$ & Gizi Baik & $\begin{array}{l}\text { Berat } \\
\text { Normal }\end{array}$ & Pendek & Gizi lebih & Tidak Sesuai \\
\hline $\begin{array}{l}1 \\
1\end{array}$ & $\begin{array}{l}\text { Gishaka Azkia } \\
\text { Asri S }\end{array}$ & $26 / 02 / 2020$ & 8,3 & 70 & $\mathrm{P}$ & $\begin{array}{l}\text { Berat } \\
\text { Normal }\end{array}$ & $\begin{array}{l}\text { Tinggi } \\
\text { Normal }\end{array}$ & $\begin{array}{l}\text { Gizi Baik } \\
\text { (Normal) }\end{array}$ & $\begin{array}{l}\text { Berat } \\
\text { Normal }\end{array}$ & $\begin{array}{l}\text { Tinggi } \\
\text { Normal }\end{array}$ & $\begin{array}{l}\text { Gizi Baik } \\
\text { (Normal) }\end{array}$ & Sesuai \\
\hline $\begin{array}{l}1 \\
2\end{array}$ & Reva Novalita & 29/11/2017 & 18.4 & 93 & P & $\begin{array}{l}\text { Resiko Berat } \\
\text { Badan } \\
\text { Berlebihan }\end{array}$ & $\begin{array}{l}\text { Tinggi } \\
\text { Normal }\end{array}$ & Obesitas & $\begin{array}{l}\text { Resiko Berat } \\
\text { Badan } \\
\text { Berlebihan }\end{array}$ & $\begin{array}{l}\text { Tinggi } \\
\text { Normal }\end{array}$ & Obesitas) & Sesuai \\
\hline
\end{tabular}

Dapat dilihat pada perhitungan nilai keanggotaan untuk simpangan baku -1SD adalah 0.82 dan nilai keanggotaan untuk simpangan baku Median adalah 0.18. Maka kesimpulan nilai keanggotaan untuk berat badan balita terhadap panjang badan adalah simpangan baku $-1 \mathrm{SD}$.

Selanjutnya dapat dilihat di Tabel 1 kategori ambang batas status gizi anak bahwa nilai ambang batas untuk simpangan baku -1SD pada indeks berat badan menurut panjang badan (BB/PB) adalah Gizi Baik (normal)

Tabel 2. Perbandingan Hasil Antara Tabel Antropometri dan Sistem 
Jurnal INFORMA Politeknik Indonusa Surakarta ISSN : 2442-7942 Vol. x Nomor x Tahun yyyy

\begin{tabular}{|c|c|c|c|c|c|c|c|c|c|c|c|c|}
\hline \multirow{2}{*}{$\begin{array}{l}\mathbf{N} \\
\mathbf{o}\end{array}$} & \multirow{2}{*}{ Nama } & \multicolumn{4}{|c|}{ Data Balita } & \multicolumn{3}{|c|}{$\begin{array}{c}\text { Hasil Perhitungan Standar } \\
\text { Antropometri }\end{array}$} & \multicolumn{3}{|c|}{ Hasil Perhitungan Sistem } & \multirow{2}{*}{ Kesimpulan } \\
\hline & & Tgl Lahir & $\begin{array}{l}\text { BB } \\
(\mathrm{kg})\end{array}$ & $\begin{array}{c}\mathbf{P B} \\
(\mathrm{cm}) \\
\end{array}$ & Sex & $\mathbf{B B} / \mathbf{U}$ & $\mathbf{P B} / \mathrm{U}$ & BB/PB & $\mathbf{B B} / \mathbf{U}$ & $\mathbf{P B} / \mathrm{U}$ & BB/PB & \\
\hline $\begin{array}{l}1 \\
3 \\
\end{array}$ & $\begin{array}{l}\text { Hamdan } \\
\text { Arasyid }\end{array}$ & $12 / 06 / 2018$ & 11,2 & 88 & $\mathrm{~L}$ & $\begin{array}{l}\text { Berat } \\
\text { Normal } \\
\end{array}$ & $\begin{array}{l}\text { Tinggi } \\
\text { Normal } \\
\end{array}$ & $\begin{array}{l}\text { Gizi Baik } \\
\text { (Normal) }\end{array}$ & $\begin{array}{l}\text { Berat } \\
\text { Normal }\end{array}$ & $\begin{array}{l}\text { Tinggi } \\
\text { Normal }\end{array}$ & $\begin{array}{l}\text { Gizi Baik } \\
\text { (Normal) }\end{array}$ & Sesuai \\
\hline $\begin{array}{l}1 \\
4 \\
\end{array}$ & $\begin{array}{l}\text { Sheza Yeslin } \\
\mathrm{C}\end{array}$ & $14 / 12 / 2018$ & 11,1 & 75 & $\mathrm{P}$ & $\begin{array}{l}\text { Berat } \\
\text { Normal } \\
\end{array}$ & $\begin{array}{l}\text { Sangat } \\
\text { Pendek }\end{array}$ & Gizi lebih & $\begin{array}{l}\text { Berat } \\
\text { Normal } \\
\end{array}$ & $\begin{array}{l}\text { Sangat } \\
\text { Pendek }\end{array}$ & Gizi lebih & Sesuai \\
\hline $\begin{array}{l}1 \\
5 \\
\end{array}$ & $\begin{array}{ll}\text { Taufik } & \mathrm{Al} \\
\text { Hakim } & \\
\end{array}$ & 09/03/2020 & 79 & 71 & $\mathrm{~L}$ & $\begin{array}{l}\text { Berat } \\
\text { Normal }\end{array}$ & $\begin{array}{l}\text { Tinggi } \\
\text { Normal }\end{array}$ & $\begin{array}{l}\text { Gizi Baik } \\
\text { (Normal) }\end{array}$ & $\begin{array}{l}\text { Berat } \\
\text { Normal }\end{array}$ & $\begin{array}{l}\text { Tinggi } \\
\text { Normal }\end{array}$ & $\begin{array}{l}\begin{array}{l}\text { Gizi Baik } \\
\text { (Normal) }\end{array} \\
\end{array}$ & Sesuai \\
\hline $\begin{array}{l}1 \\
6 \\
\end{array}$ & $\begin{array}{l}\text { Kienan Saihan } \\
\text { Adam }\end{array}$ & $16 / 04 / 2020$ & 7,1 & 68 & $\mathrm{~L}$ & $\begin{array}{l}\text { Berat } \\
\text { Normal } \\
\end{array}$ & $\begin{array}{l}\text { Tinggi } \\
\text { Normal } \\
\end{array}$ & $\begin{array}{l}\text { Gizi Baik } \\
\text { (Normal) }\end{array}$ & $\begin{array}{l}\text { Berat } \\
\text { Normal } \\
\end{array}$ & $\begin{array}{l}\text { Tinggi } \\
\text { Normal } \\
\end{array}$ & $\begin{array}{l}\text { Gizi Baik } \\
\text { (Normal) }\end{array}$ & Sesuai \\
\hline $\begin{array}{l}1 \\
7 \\
\end{array}$ & $\begin{array}{l}\text { Tara Ramdan } \\
\text { S }\end{array}$ & $28 / 04 / 2020$ & 7.3 & 68 & $\mathrm{~L}$ & $\begin{array}{l}\text { Berat } \\
\text { Normal } \\
\end{array}$ & $\begin{array}{l}\text { Tinggi } \\
\text { Normal }\end{array}$ & $\begin{array}{l}\text { Gizi Baik } \\
\text { (Normal) }\end{array}$ & $\begin{array}{l}\text { Berat } \\
\text { Normal }\end{array}$ & $\begin{array}{l}\text { Tinggi } \\
\text { Normal }\end{array}$ & $\begin{array}{l}\text { Gizi Baik } \\
\text { (Normal) }\end{array}$ & Sesuai \\
\hline $\begin{array}{l}1 \\
8 \\
\end{array}$ & $\begin{array}{ll}\text { Raifal } & \mathrm{R} \\
\text { Alvano } & \\
\end{array}$ & $24 / 06 / 2020$ & 7.5 & 58 & $\mathrm{~L}$ & $\begin{array}{l}\text { Berat } \\
\text { Normal } \\
\end{array}$ & $\begin{array}{l}\text { Sangat } \\
\text { Pendek }\end{array}$ & Obesitas & $\begin{array}{l}\text { Berat } \\
\text { Normal } \\
\end{array}$ & $\begin{array}{l}\text { Sangat } \\
\text { Pendek }\end{array}$ & Obesitas & Sesuai \\
\hline $\begin{array}{l}1 \\
9\end{array}$ & $\begin{array}{l}\text { Clarisa } \\
\text { Pratista A }\end{array}$ & $28 / 12 / 2019$ & 7.6 & 67 & $P$ & $\begin{array}{l}\text { Berat } \\
\text { Normal }\end{array}$ & Pendek & $\begin{array}{l}\text { Gizi Baik } \\
\text { (Normal) }\end{array}$ & $\begin{array}{l}\text { Berat } \\
\text { Normal }\end{array}$ & Pendek & $\begin{array}{l}\text { Gizi Baik } \\
\text { (Normal) }\end{array}$ & Sesuai \\
\hline $\begin{array}{l}2 \\
0\end{array}$ & $\begin{array}{l}\text { Oktavian } \\
\text { Nugraha }\end{array}$ & $22 / 09 / 2020$ & 4.7 & 57 & $\mathrm{~L}$ & $\begin{array}{l}\text { Berat } \\
\text { Normal }\end{array}$ & $\begin{array}{l}\text { Tinggi } \\
\text { Normal }\end{array}$ & $\begin{array}{l}\text { Gizi Baik } \\
\text { (Normal) }\end{array}$ & $\begin{array}{l}\text { Berat } \\
\text { Normal }\end{array}$ & $\begin{array}{l}\text { Tinggi } \\
\text { Normal }\end{array}$ & $\begin{array}{l}\begin{array}{l}\text { Gizi Baik } \\
\text { (Normal) }\end{array} \\
\text { (Nol }\end{array}$ & Sesuai \\
\hline $\begin{array}{l}2 \\
1 \\
\end{array}$ & $\begin{array}{l}\text { M. Raka } \\
\text { Maulana }\end{array}$ & $23 / 12 / 2015$ & 13,3 & 98 & $\mathrm{~L}$ & $\begin{array}{l}\text { Berat Badan } \\
\text { Kurang }\end{array}$ & Pendek & $\begin{array}{l}\text { Gizi Baik } \\
\text { (Normal) }\end{array}$ & $\begin{array}{l}\text { Berat Badan } \\
\text { Kurang }\end{array}$ & Pendek & $\begin{array}{l}\begin{array}{l}\text { Gizi Baik } \\
\text { (Normal) }\end{array} \\
\end{array}$ & Sesuai \\
\hline $\begin{array}{l}2 \\
2 \\
\end{array}$ & $\begin{array}{l}\text { Kinara Qurana } \\
\text { Aini }\end{array}$ & $14 / 02 / 2016$ & 13,6 & 96 & P & $\begin{array}{l}\text { Berat } \\
\text { Normal }\end{array}$ & Pendek & $\begin{array}{l}\text { Gizi Baik } \\
\text { (Normal) }\end{array}$ & $\begin{array}{l}\text { Berat Badan } \\
\text { Kurang }\end{array}$ & $\begin{array}{l}\text { Sangat } \\
\text { Pendek }\end{array}$ & $\begin{array}{l}\text { Gizi Baik } \\
\text { (Normal) }\end{array}$ & Tidak Sesuai \\
\hline $\begin{array}{l}2 \\
3\end{array}$ & $\begin{array}{l}\text { Keisha } \\
\text { Anindita } \\
\text { Sahra }\end{array}$ & $20 / 02 / 2016$ & 15,3 & 98 & $\mathrm{P}$ & $\begin{array}{l}\text { Berat } \\
\text { Normal }\end{array}$ & Pendek & $\begin{array}{l}\text { Gizi Baik } \\
\text { (Normal) }\end{array}$ & $\begin{array}{l}\text { Berat } \\
\text { Normal }\end{array}$ & Pendek & $\begin{array}{l}\text { Gizi Baik } \\
\text { (Normal) }\end{array}$ & Sesuai \\
\hline $\begin{array}{l}2 \\
4\end{array}$ & $\begin{array}{l}\text { Jordi Nauval } \\
\text { Sadega }\end{array}$ & $22 / 03 / 2016$ & 16,2 & 102 & $\mathrm{~L}$ & $\begin{array}{l}\text { Berat } \\
\text { Normal }\end{array}$ & $\begin{array}{l}\text { Tinggi } \\
\text { Normal }\end{array}$ & $\begin{array}{l}\text { Gizi Baik } \\
\text { (Normal) }\end{array}$ & $\begin{array}{l}\text { Berat } \\
\text { Normal }\end{array}$ & $\begin{array}{l}\text { Tinggi } \\
\text { Normal }\end{array}$ & $\begin{array}{l}\text { Gizi Baik } \\
\text { (Normal) }\end{array}$ & Sesuai \\
\hline $\begin{array}{l}2 \\
5 \\
\end{array}$ & $\begin{array}{l}\text { Wikan Azka } \\
\text { Ramadan }\end{array}$ & 03/07/2016 & 14,2 & 97 & $\mathrm{~L}$ & $\begin{array}{l}\text { Berat } \\
\text { Normal } \\
\end{array}$ & Pendek & $\begin{array}{l}\begin{array}{l}\text { Gizi Baik } \\
\text { (Normal) }\end{array} \\
\end{array}$ & $\begin{array}{l}\text { Berat Badan } \\
\text { Kurang }\end{array}$ & Pendek & $\begin{array}{l}\begin{array}{l}\text { Gizi Baik } \\
\text { (Normal) }\end{array} \\
\end{array}$ & Tidak Sesuai \\
\hline $\begin{array}{l}2 \\
6\end{array}$ & $\begin{array}{ll}\text { Resta } & \text { Fara } \\
\text { Iftina } & \end{array}$ & $11 / 11 / 2016$ & 20,6 & 99 & $P$ & $\begin{array}{l}\text { Risiko Berat } \\
\text { Badan } \\
\text { Berlebih }\end{array}$ & $\begin{array}{l}\text { Tinggi } \\
\text { Normal }\end{array}$ & Obesitas & $\begin{array}{l}\text { Risiko Berat } \\
\text { Badan } \\
\text { Berlebih }\end{array}$ & $\begin{array}{l}\text { Tinggi } \\
\text { Normal }\end{array}$ & Obesitas & Sesuai \\
\hline $\begin{array}{l}2 \\
7 \\
\end{array}$ & $\begin{array}{l}\text { Viska Dewi } \\
\text { Rengganis }\end{array}$ & 22/03/2017 & 14,5 & 100 & P & $\begin{array}{l}\text { Berat } \\
\text { Normal }\end{array}$ & $\begin{array}{l}\text { Tinggi } \\
\text { Normal }\end{array}$ & $\begin{array}{l}\text { Gizi Baik } \\
\text { (Normal) }\end{array}$ & $\begin{array}{l}\text { Berat } \\
\text { Normal }\end{array}$ & $\begin{array}{l}\text { Tinggi } \\
\text { Normal }\end{array}$ & $\begin{array}{l}\begin{array}{l}\text { Gizi Baik } \\
\text { (Normal) }\end{array} \\
\end{array}$ & Sesuai \\
\hline $\begin{array}{l}2 \\
8 \\
\end{array}$ & $\begin{array}{l}\text { Jaffan Arvino } \\
\text { Raffasya }\end{array}$ & $13 / 11 / 2017$ & 13 & 90 & $\mathrm{~L}$ & $\begin{array}{l}\text { Berat } \\
\text { Normal }\end{array}$ & $\begin{array}{l}\text { Tinggi } \\
\text { Normal } \\
\end{array}$ & $\begin{array}{l}\begin{array}{l}\text { Gizi Baik } \\
\text { (Normal) }\end{array} \\
\end{array}$ & $\begin{array}{l}\text { Berat } \\
\text { Normal }\end{array}$ & Pendek & $\begin{array}{l}\begin{array}{l}\text { Gizi Baik } \\
\text { (Normal) }\end{array} \\
\end{array}$ & Tidak Sesuai \\
\hline $\begin{array}{l}2 \\
9 \\
\end{array}$ & Iqbal Arsalam & $06 / 01 / 2018$ & 12,7 & 88 & $\mathrm{~L}$ & $\begin{array}{l}\text { Berat } \\
\text { Normal }\end{array}$ & Pendek & $\begin{array}{l}\text { Gizi Baik } \\
\text { (Normal) }\end{array}$ & $\begin{array}{l}\text { Berat } \\
\text { Normal }\end{array}$ & Pendek & $\begin{array}{l}\begin{array}{l}\text { Gizi Baik } \\
\text { (Normal) }\end{array} \\
\end{array}$ & Sesuai \\
\hline $\begin{array}{l}3 \\
0 \\
\end{array}$ & $\begin{array}{l}\text { Nadhifa } \\
\text { Zalika Arsyila } \\
\end{array}$ & $13 / 09 / 2018$ & 10,1 & 80 & $\mathrm{P}$ & $\begin{array}{l}\text { Berat } \\
\text { Normal }\end{array}$ & Pendek & Pendek & $\begin{array}{l}\text { Berat } \\
\text { Normal }\end{array}$ & Pendek & $\begin{array}{l}\begin{array}{l}\text { Gizi Baik } \\
\text { (Normal) }\end{array} \\
\end{array}$ & Sesuai \\
\hline $\begin{array}{l}3 \\
1\end{array}$ & $\begin{array}{l}\text { Rifvi Oktavia } \\
\text { Putri }\end{array}$ & $30 / 10 / 2018$ & 16,1 & 88 & $\mathrm{P}$ & $\begin{array}{l}\text { Risiko Berat } \\
\text { Badan } \\
\text { Berlebih }\end{array}$ & $\begin{array}{l}\text { Tinggi } \\
\text { Normal }\end{array}$ & Obesitas & $\begin{array}{l}\text { Risiko Berat } \\
\text { Badan } \\
\text { Berlebih }\end{array}$ & $\begin{array}{l}\text { Tinggi } \\
\text { Normal }\end{array}$ & Obesitas & Sesuai \\
\hline $\begin{array}{l}3 \\
2 \\
\end{array}$ & Fauzan Anafis & $15 / 01 / 2020$ & 9,5 & 64 & $\mathrm{~L}$ & $\begin{array}{l}\text { Berat } \\
\text { Normal }\end{array}$ & $\begin{array}{l}\text { Sangat } \\
\text { Pendek }\end{array}$ & Obesitas & $\begin{array}{l}\text { Berat } \\
\text { Normal }\end{array}$ & $\begin{array}{l}\text { Sangat } \\
\text { Pendek }\end{array}$ & Obesitas & Sesuai \\
\hline $\begin{array}{l}3 \\
3 \\
\end{array}$ & Ragil Febri S & $15 / 02 / 2020$ & 9,7 & 65 & $\mathrm{~L}$ & $\begin{array}{l}\text { Berat } \\
\text { Normal }\end{array}$ & $\begin{array}{l}\text { Sangat } \\
\text { Pendek }\end{array}$ & Obesitas & $\begin{array}{l}\text { Berat } \\
\text { Normal }\end{array}$ & $\begin{array}{l}\text { Sangat } \\
\text { Pendek }\end{array}$ & Obesitas & Sesuai \\
\hline $\begin{array}{l}3 \\
4 \\
\end{array}$ & $\begin{array}{l}\text { Nasyafarin } \\
\text { Yumna }\end{array}$ & 04/08/2019 & 8,7 & 72 & $\mathrm{P}$ & $\begin{array}{l}\text { Berat } \\
\text { Normal }\end{array}$ & Pendek & $\begin{array}{l}\text { Gizi Baik } \\
\text { (Normal) }\end{array}$ & $\begin{array}{l}\text { Berat } \\
\text { Normal }\end{array}$ & Pendek & $\begin{array}{l}\text { Gizi Baik } \\
\text { (Normal) }\end{array}$ & Sesuai \\
\hline $\begin{array}{l}3 \\
5 \\
\end{array}$ & $\begin{array}{l}\text { Farzana } \\
\text { Anasya }\end{array}$ & $10 / 06 / 2016$ & 14,1 & 100 & $\mathrm{P}$ & $\begin{array}{l}\text { Berat } \\
\text { Normal }\end{array}$ & $\begin{array}{l}\text { Tinggi } \\
\text { Normal }\end{array}$ & $\begin{array}{l}\text { Gizi Baik } \\
\text { (Normal) }\end{array}$ & $\begin{array}{l}\text { Berat } \\
\text { Normal }\end{array}$ & $\begin{array}{l}\text { Tinggi } \\
\text { Normal }\end{array}$ & $\begin{array}{l}\text { Gizi Baik } \\
\text { (Normal) }\end{array}$ & Sesuai \\
\hline
\end{tabular}

Dari keseluruhan data balita yaitu 35 data hasil pengujian dapat dirumuskan sebagai berikut : Jumlah data yang sesuai

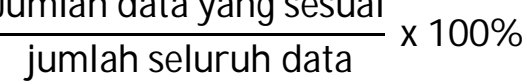

maka didapatkan tingkat akurasi sebagai berikut :

$$
\frac{30}{35} \times 100 \%=85.71 \%
$$

\section{KESIMPULAN}

Berdasarkan hasil penelitian yang telah dilakukan, dapat diperoleh kesimpulan bahwa perhitungan sistem dengan metode fuzzy Tahani dan perhitungan menggunakan standar baku antropometri memiliki hasil $85,71 \%$ dari 35 data yang diujikan terdapat 5 yang tidak sesuai, sehingga dapat disimpulkan bahwa unjuk kerja sistem berhasil.

\section{REFERENSI}

Anita, F. (2016). Fuzzy Logic Untuk Menentukan Status Gizi Pada Rumah Sakit M.Zein Painan Pessel. JURNAL MANAJEMEN PENDIDIKAN Vol. I No.1 Th. 2016.

Astari, A., \& Komarudin, R. (2018). Sistem Pendukung Keputusan Pemilihan Karyawan Terbaik Dengan Menggunakan Metode Fuzzy Tahani. Jurnal Penelitian Ilmu Komputer, System Embedded \& Logic p-ISSN: 2303-3304, e-ISSN: 2620-3553 6 (2): 169 - 178 (September 2018).

Febrealti, E. R. (2011). Sistem Penentuan Status Gizi Balita Menggunakan Metode K-NN (K-NEAREST NEIGHBOR). Riau.

Fidiantoro, N., \& Setiadi, T. (2013). Model Penentuan Status Gizi di Puskesmas. Jurnal Sarjana Teknik Informatika Volume 1 Nomor 1, Juni 2013.

Gufron, A. (2010). Penerapan Fuzzy Logic dalam Sistem Kenaikan Jabatan (Studi 
Kasus : PT. Krakatau Daya Listrik Cilegon ). Jakarta.

Kemenkes, R. I. (2020). Standar Antropometri Anak. Jakarta.

Proverawati, A., \& Asfuah, S. (2009). Buku Ajar Gizi untuk Kebidanan. Yogyakarta: Nuha Medika.

Rahmawati, I., Hasanah, H., \& Maulindar, J. (2017). Aplikasi Monitoring Status Gizi Tubuh Balita dengan Metode Z Score Berbasis Android. in Seminar Nasional Teknologi Informasi dan Bisnis (SENATIB), 2017, pp. 147-154.

Sari, D., Dewanto, W., \& Surateno. (2017). Aplikasi Pemantauan Status Gizi Berdasarkan Pengukuran Antropometri Menggunakan Metode Fuzzy Logic. Jurnal Teknologi Informatika dan Terapan Vol. 04, No 01, Januari - Juni 2017 ISSN: 235-838X.

Ulansari, A., Amini, S., \& Mulyati, S. (2019). Sistem Pendukung Keputusan Gizi Balita Menggunakan Metode Simple Additive Weighting Berbasis WEB. Proceeding SINTAK 2019, Hal 435.

Wulandari, Y. (2011). Aplikasi Metode Mamdani Dalam Penentuan Status Gizi Dengan Indeks Massa Tubuh (IMT) Menggunakan Logika Fuzzy. Yogyakarta. 